\title{
QUANTITATIVE AND QUALITATIVE ANALYSIS OF COLLAGEN TYPES IN THE FASCIA TRANSVERSALIS OF INGUINAL HERNIA PATIENTS
}

\author{
Alberto Luiz Monteiro MEYER ${ }^{1}$, Eduardo BERGER ${ }^{1}$, Orlando MONTEIRO Jr.', \\ Paulino Alberto ALONSO', João Norberto STAVALE² and Marcelo Paulo Serafim GONÇALVES ${ }^{1}$
}

\begin{abstract}
Background - Inguinal hernia is the second most common surgical case in our field. The anatomical factors alone are not enough to explain the inguinal hernia. Studies show changes in the proportion and quantity of collagen fibers in the developing of inguinal hernia. The greater production of collagen type III compared to the type I could justify the thinning of the fascia transversalis and its weakness. Aim - To determine the quantitative and qualitative changes of collagen in the fascia transversalis in inguinal hernia patients and compare them to findings from corpses without inguinal hernia. Method - Prospective case-control study based on the biopsy of fascia transversalis of 27 patients and 24 corpses. The technique used was hematoxylin-eosin and picrosirius colorimetry. Results - The medium percent area of collagen (types I + III) and collagen type I, in both groups, show no statistic difference. The quantity of collagen type III was greater in the patients. Patients classified with Nyhus IIIa presented greater quantity of collagen type III. Conclusion - There is no significant difference in the quantity of collagen in the fascia transversalis of patients compared to the controls. An increase in the quantity of collagen type III was found in patients with inguinal hernia and a greater quantity in those patients classified with Nyhus IIIa.
\end{abstract}

HEADINGS - Hernia, inguinal. Fascia. Collagen.

\section{INTRODUCTION}

Inguinal hernia is the second most common surgical case in our field. It is estimated that 1 in 5 men and 1 in 17 women can develop it along their lives. In Brazil, according to data from Health Department (DATA-SUS), about 200.000 inguinal hernias are surgically corrected in public hospitals. If you add the 80.000 cases treated in private medicine it is proper to understand the real social and economical dimension performed by this disease ${ }^{(22)}$.

The bases of inguinal hernia, which are eminently surgical, were established in the later period of last century. However, the percentage of recurrent cases vary from $2 \%$ to $10 \%$ (according to the technique used) and the failures can be connected to the conditions of the patient him/herself.

The association of anatomical abnormalities (high insertion of the internal oblique muscle, widening of the internal inguinal ring and persistency of the vaginal peritoneum conduct) with the increase in the intra-abdominal pressure have been attributed to its etiopathogeny ${ }^{(1,7)}$.

The anatomical factors, isolated, are not enough to explain the inguinal hernias themselves. It becomes evident when one evaluates children suffering from a clear vaginal process - from whom, less than half, present a detectable hernia $^{(9)}$. Moreover, the appearance if indirect inguinal hernias in men older than 40 years old and recurrent hernias after technically adequate surgeries, probably have in their etiology not only anatomical changes.

On the other hand, it has been shown the association of diseases in the connective tissue with the appearance of inguinal hernia as in the Marfan syndrome, EhlersDanlos syndrome e osteogenesis imperfecta ${ }^{(13)}$.

Because it is aponeurosis, the posterior wall has as basic structure the collagen fibers. All studies recognize the role of the collagen in attributing structural resistance and integrity to the aponeurosis and fascias ${ }^{(2)}$. In this condition the presence in adequate amount as well as the collagen properties are essential for the functionality of fascia transversalis. This fascia confers internal support to the lateral wall of the abdomen and extends itself, in the caudal direction, to form the coating in the inguinal region. The surgical importance of fascia transversalis reside in the fact that it is the last layer in the aponeurotic muscle of the abdomen.

In the past decades, studies on the importance of the frailty of fascia transversalis, showing changes in the proportion and amount of collagen fibers in the developing of inguinal hernia, were carried out ${ }^{(17)}$.

Departaments of 'Surgery and 'Pathology, Hospital "Professor Edmundo Vasconcelos", São Paulo, SP, Brazil.

Correspondence: Dr. Alberto Luiz Monteiro Meyer - Hospital Professor Edmundo Vasconcelos - Rua Borges Lagoa, 1231 conj. 54 - $04038-033$ - São Paulo, SP, Brazil. E-mail: almmeyer@yahoo.com 
Recently, evidence came up conveying quantitative and qualitative deficiencies of collagen type I and type III in several parts of the human body ${ }^{(8)}$.

Collagen type I organizes itself forming fibrils, which then unite to make up thicker fibers, classically denominated collagen fibers, which present great resistance to the tension forces and are also not elastic. Type I is found mainly in the dermis, tendon, bone, ligament and cornea. In the histological cuts colored using hematoxylineosin (H-E), the collagen fibers are stained pink by eosin, blue by Mallory trichrome, and green by Gomori trichrome ${ }^{(15)}$.

Collagen type III organizes itself forming a loose mesh in several supportive tissues. The fibrils constituted by collagen type III are classically known as reticular fibers and can be found in blood vessels, marrow bone, lymph tissue, flat muscle, nerve, lungs and fetal skin. They can be visualized after special techniques are used, such as the silver staining, PAS method (periodic acid + Schiff reaction) and pricosirius ${ }^{(15)}$

The greater production of collagen type III compared to type I could justify the widening of the fascia transversalis and its weakness ${ }^{(22)}$.

The present study is based on the possibility that there is an association between the proportions and quantity of fascia transversalis main matrix - the collagen - and the weakening of the posterior wall of the inguinal canal, as a peculiar condition to herniogenese.

The goal consists in determining the quantitative and qualitative changes of collagen in the fascia transversalis of inguinal hernia patients and compare them to the findings in inguinal hernia-free corpses.

The different types of inguinal hernia will be layered using the Nyhus classification so that the comparison between both groups can be detailed.

\section{METHOD}

A prospective case-control study was carried out at the "Professor Edmundo Vasconcelos" Hospital (HPEV) and at the Autopsy Service of São Paulo, SP, Brazil - SVOC/USP, between January and September of 2004.

In the case group, 27 patients were selected randomly and they were assisted at the general surgery infirmary of HPEV and diagnosed as having inguinal hernia.

The criteria for inclusion adopted were: inguinal hernia patients diagnosed less than 5 years, male, consent forms signed aged 20-65.

The criteria for discard were: those taking medicine, diabetes mellitus cases, high blood pressure cases, chronic obstructive lung disease cases, Marfan syndrome cases, Ehlers-Danlos syndrome cases, and smokers when not in agreement with the study.

In the control group there were 24 corpses which had passed away less than 8 hours and whose the consent forms had been signed by family-members and which had no previous case of hernia.

The patients were submitted to an inguinal hernia repair by means of Lichteinstein technique to determine the Nyhus classification for the inguinal hernia. During surgery, a fragment of $0,5 \times 0,5 \mathrm{~cm}$ of fascia transversalis was removed (incision biopsy) from the Hasselbach triangle.
In the control group, samples of the fascia transversalis were harvested during the autopsies carried out in the SVOC/USP. The time between harvesting and fixation of the material was no longer than 8 hours so that there would not be difference in the comparison with the in vivo tissue (hernia patients).

The fascia transversalis portion of both groups was fixated in formol at $10 \%$ and was sent to the Pathological Anatomy Service at HPEV.

When both group number of samples was completed, a code table was created so that a later evaluation from the pathologist would not be subject to an inclination.

The material was soaked into paraffin and $\mathrm{H}-\mathrm{E}^{(15)}$ coloring was used. After discovering it was dense connective tissue, the following step was taken - the Picrosirius coloring. The evaluation of the Picrosirius slides was done by means of polarized light using two-interfaced lens in microscope. Through this method, the presence of collagen types I and III and their subjective amount were analyzed. The same pathologist analyzed all samples.

For the analysis of the results the Student $t$ test for independent samples was applied. In all tests the level of rejection of the nullity hypothesis was fixed in 0.05 - i.e., $5 \%$ and all meaningful values were marked by an asterisk.

The Medical Ethics Commission of HPEV approved this study protocol.

\section{RESULTS}

The patient's average age was of 53 years old, varying from $32-65$ years old $($ medium $=54$; standard deviation $=10$ ). In the control cases, the average was 53 years old, varying from 34 to 65 years old $($ medium $=59.9$; standard deviation $=11)$.

The predominant fascia tissue in both cases was the dense connective, formed mainly by collagen fibers and by adipose and muscle in a smaller percentage.

The average percent area of collagen (type I + type III) in the patients' and controls' fascia did not show any statistical meaningful difference $(P=0.876)$ and the amount found is shown in Table 1.

The quantity of collagen was determined by H-E coloring (Figures 1 and 2).

Later it was analyzed the presence of collagen type I - which main characteristic are thicker fibers, strongly birefringent and red-orangish and collagen type III - which main characteristic are thinner and more disperse fibers, little birefringent and greenish, colored by Pricosirius (Figures 3 and 4).

It was not found a statistically meaningful difference $(P=0.788)$ in the amount of collagen type I in the fascia of the patients and of the controls. On the other hand, a greater amount of collagen

TABLE 1. Collagen average rate in fascia

\begin{tabular}{lcc}
\hline & Patients & Controls \\
\cline { 2 - 3 } Collagen average rate $(\%)$ & $73( \pm 19)$ & $73( \pm 23.96)$ \\
& &
\end{tabular}

average rate \pm standard deviatio 


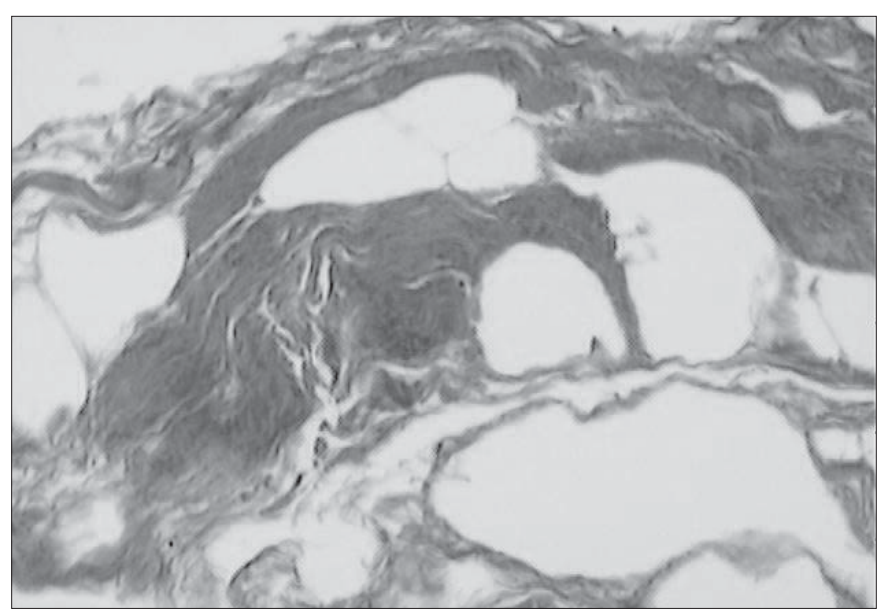

FIGURE 1. Fascia transversalis of a corpse (control) showing collagen in pink-redish color (H-E 200x)

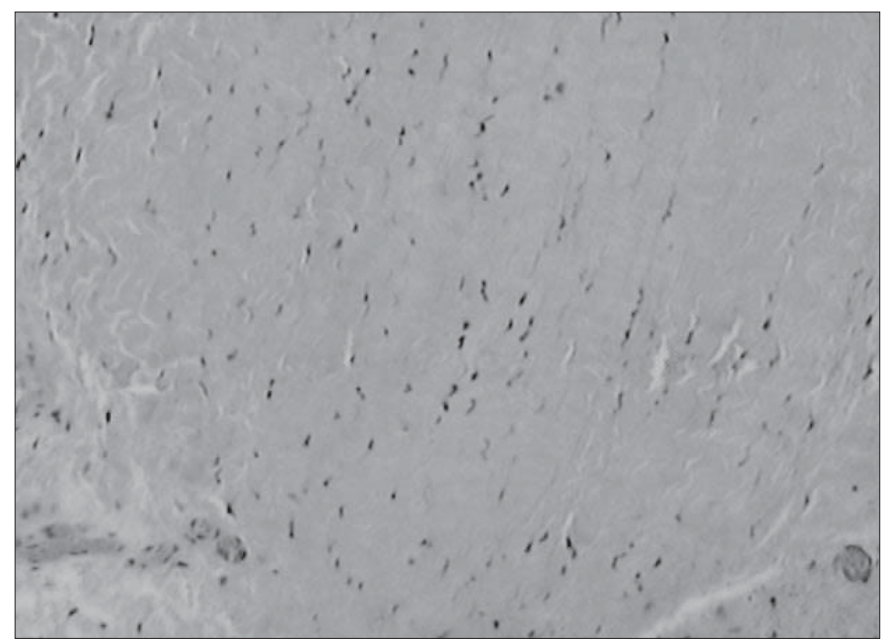

FIGURE 2. Fascia transversalis of a corpse (control) showing collagen in pink-redish color (H-E 400x)

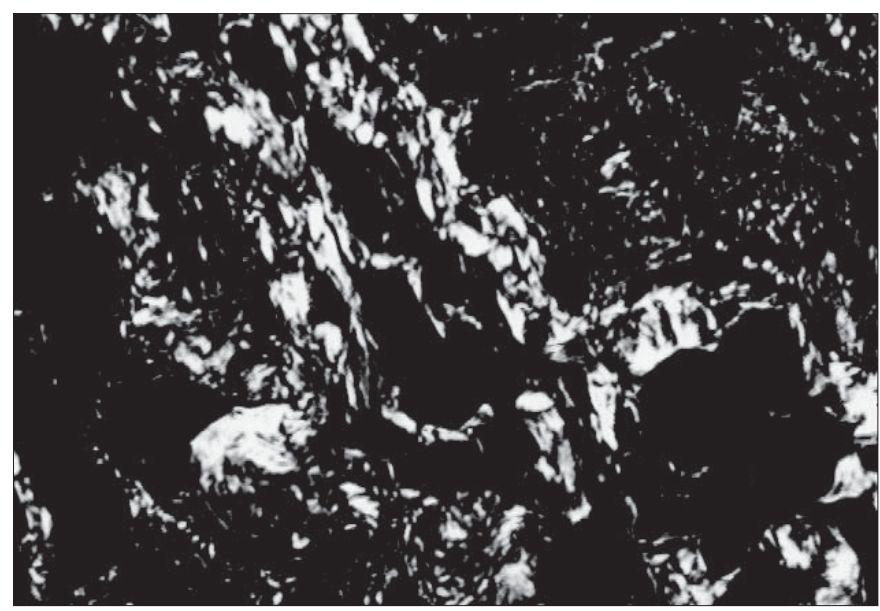

FIGURE 3. Fascia transversalis of a corpse (control) using Pricosirius coloring enhanced 400 times (400x). type III was found in the patients, which showed a statistical meaningful difference $(P=0.0220)$ as seen in Figure 5 .

In Table 2, we compared the amount of collagen type III superior to $5 \%$ - in the sample field - to the Nyhus classification for inguinal hernia. The patients classified as Nyhus IIIa had a greater amount of collagen type III with statistical meaningful difference $(P=0.033)$.

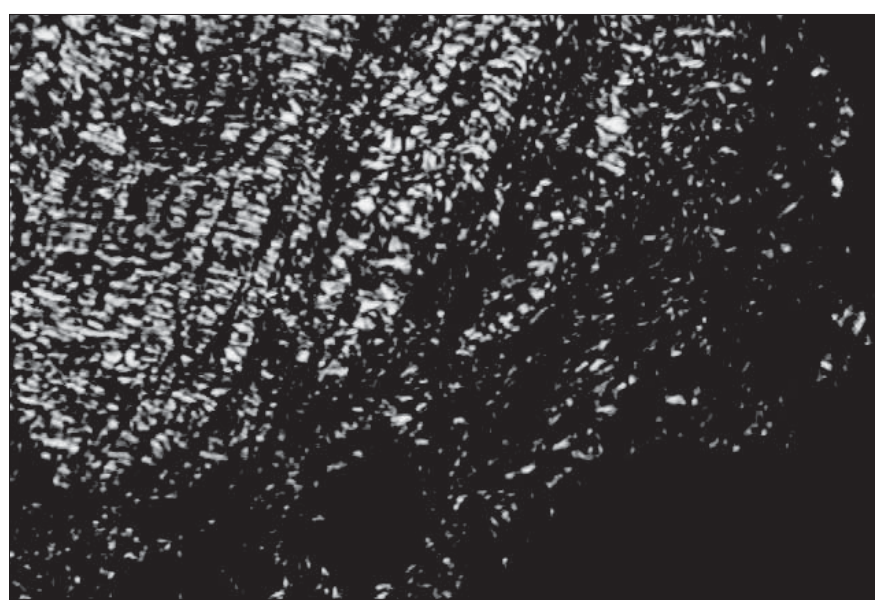

FIGURE 4. Fascia transversalis of a corpse (control) using Pricosirius coloring enhanced 400 times $(400 x)$

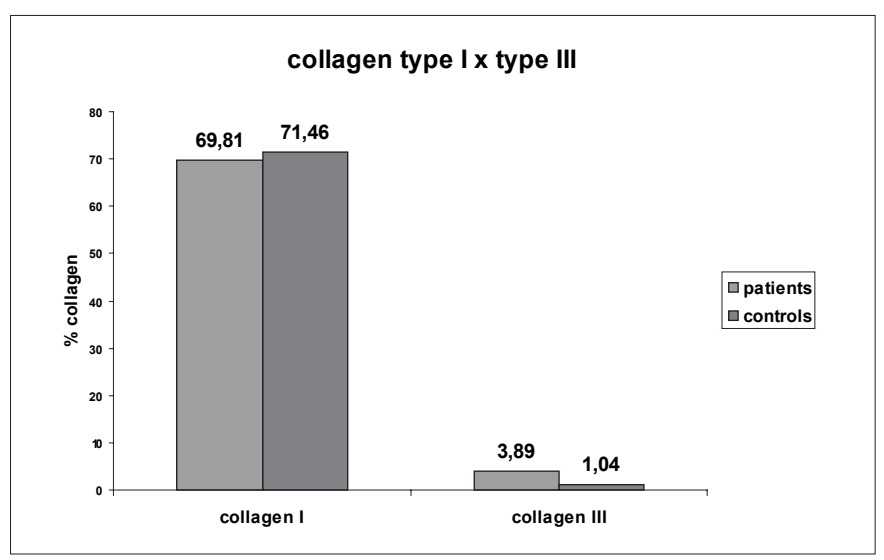

FIGURE 5. Comparison between collagen type I and type III found in patients and controls

TABLE 2. Nyhus classification and collagen type III $>5 \%$

\begin{tabular}{lcc}
\hline Classification & Patients & Collagen type III $>5 \%$ \\
\hline Nyhus I & 0 & 0 \\
Nyhus II & 6 & 1 \\
Nyhus III & & \\
$\quad$ a & 14 & 9 \\
b & 2 & 1 \\
$\quad$ c & 1 & 0 \\
Nyhus IV & 4 & 0 \\
\hline
\end{tabular}

$P=0.033^{*}$, Student $t$ test

Nyhus I - indirect inguinal hernia (internal inguinal ring without dilatation), Nyhus II - indirect inguinal hernia inguinal hernia, $c$ - femoral hernial. Nyhus IV - recuring hernias 


\section{DISCUSSION}

Hernia is one of the most common surgical cases, and which demand from the surgeons a refined anatomical and technical knowledge. Nevertheless, our knowledge of the biochemical and metabolic mechanisms, which incur in the hernia etiopathology is little.

The thickness of the thinner aponeurosis of the rectus abdominis and less weight in area in patients with direct inguinal hernia was stated by READ ${ }^{(21)}$. This, among other authors, have always alluded to the hypothesis that interference process on the amount of collagen in these aponeurosis would equally reflect in the fascia transversalis ${ }^{(5,6)}$.

WAGH and READ ${ }^{(25)}$ observations regarding the presence of sheath in the frailer rectus abdominis muscle, having less weight in area than in the controls, and, more evidently in the bilateral hernia patients, arouse doubts regarding the presence of desired amounts of collagen in the inguinal region.

Few studies have based themselves in samples of fascia transversalis in inguinal hernia patients to access the distribution of the constituent elements and quantify the collagen. The histological cuts colored using Pricosirius and observed by polarized light are an adequate method to identify mainly types I and III from the collagen types. It was used a imagecapturing process via video and quantification via coloring, by means of a computer software as shown in other studies ${ }^{(20,28)}$. The analysis carried out by WOLWACZ et al. ${ }^{(27)}$ showed an average percent collagen area in the patients, 33\% smaller than in the controls.

On the other hand, PEACOCK ${ }^{(19)}$ measured biochemically the total amount of collagen in the fascia of recurrent hernia patients and, by selfpairing, could not find altered amounts. BELLÓN et al. ${ }^{(3)}$ could also not find meaningful differences in the amount of collagen in their patients group.

Our results show that, after comparing the amount of collagen in the samples, we could conclude that the average percent area of collagen in the sample field of the patients did not present statistical meaningful difference to that of the controls. An approximate $73 \%$ amount of collagen was found in the fascia transversalis, very similar to the literature that states values of approximately $75 \%$ as the average ${ }^{(26)}$.

After performing the quantitative analysis of the collagen, BORQUEZ et al. ${ }^{(4)}$ showed that the density of the collagen fibers was $52 \%$ smaller in inguinal hernia patients and concluded that there are qualitative changes in the density of the collagen fibers.

FRIEDMAN et al. ${ }^{(8)}$ noticed the substitution of collagen type I by collagen type III, which is a tissue that has less tensional strength and elastic resistance in its work. Other authors showed changes in the proportions of collagen types I and III in inguinal hernia patients ${ }^{(4,11)}$. KLINGE et al. ${ }^{(10)}$ published pieces of work in which they show changes in the connective tissue of inguinal hernia patients by measuring the proportion of collagen type I and III using immunohistochemistry, western blot and protein electrophoresis. A significant smaller value was demonstrated in inguinal hernia patients, without, nevertheless, having any difference between direct and indirect inguinal hernia.

The genetic expression of collagen type I and III in fibroblasts derived from skin was studied by ROSH et al. ${ }^{(23)}$. The measuring was carried out using the Reverse Transcriptase Polymerase Chain Reaction technique to measure the messenger RNA of the procollagen chain and it also obtained a diminished proportion of collagen types I and III.

Likewise, the analysis performed in this work has made evident a qualitative change of the collagen fibers, showing a greater amount of collagen type III in the patients compared to the controls.

The qualitative investigation of collagen carried out by PANS et al. ${ }^{(18)}$ did not show a meaningful difference between the fascia of the patients and controls, however, there was an increase in the concentration of collagen in indirect inguinal hernia in the fascia transversalis of patients diagnosed with direct inguinal hernia.

In this study one can observe a greater concentration of collagen type III in patients diagnosed with direct inguinal hernia (Nyhus IIIa), which can reflect a remodeling process in the connective tissue.

\section{CONCLUSION}

There was no meaningful difference in the amount of collagen in the fascia transversalis of the patients compared to the controls, however, a qualitative difference in the amount of collagen was found, which makes it evident a meaningful increase of collagen type III in inguinal hernia patients.

Based on the result, inguinal hernia patients classified as Nyhus IIIa have greater amount of collagen type III when compared to the other inguinal hernia patients. 
Meyer ALM, Berger E, Monteiro Jr O, Alonso PA, Stavale JN, Gonçalves MPS. A fascia transversalis na etiopatogenia da hérnia inguinal. Arq Gastroenterol. 2007;44(3):230-4.

RESUMO - Racional - A hérnia inguinal é a segunda afecção cirúrgica mais comum em nosso meio. Os fatores anatômicos, isoladamente, não são suficientes para explicar a ocorrência das hérnias inguinais. Estudos apontam alterações na proporção e quantidade de fibras colágenas no desenvolvimento da hérnia inguinal. A maior produção de colágeno tipo III em relação ao tipo I poderia justificar o adelgaçamento da fascia transversalis e sua fraqueza. Objetivo - Determinar as alterações quantitativas e qualitativas de colágeno na fascia transversalis de doentes com hérnia inguinal e compará-las com achados em cadáveres sem hérnia inguinal. Método - Estudo prospectivo caso-controle com análise de biopsia de fascia transversalis de 27 doentes e 24 cadáveres. Utilizou-se a técnica de coloração de hematoxilina-eosina e picrosirius. Resultados - A área percentual média de colágeno (tipo I + tipo III) e colágeno tipo I, nos dois grupos, não apresentou diferença estatística. A quantidade de colágeno tipo III foi maior nos doentes. Doentes classificados com Nyhus IIIa apresentaram maior quantidade de colágeno tipo III. Conclusão - Não há diferença significativa na quantidade de colágeno em fascia transversalis de doentes comparados com controles. Foi encontrado aumento na quantidade de colágeno tipo III nos doentes com hérnia e em maior quantidade nos doentes classificados como Nyhus IIIa.

DESCRITORES - Hérnia inguinal. Fascia. Colágeno.

\section{REFERENCES}

1. Abrahamson J. Etiology and pathophysiology of primary and recurrent groin hernia formation. Surg Clin North Am. 1998;78:953-72.

2. Ajabnoor MA, Mokhtar AM, Rafee AA, Taha AM. Defective collagen metabolism in Saudi patients with hernia. Ann Clin Biochem. 1992;29 (Pt 4) :430-6.

3. Bellón JM, Buján J, Honduvilla NG, Jurado F, Gimeno MJ, Turnay J, Olmo N, Lizarbe MA. Study of biochemical substrate and role of metalloproteinases in fascia transversalis from hernial processes. Eur J Clin Invest. 1997;27:510-6.

4. Bòrquez PM, Garrido LO, Manterola CD, Peña PS, Schlageter CT, Orellana JJC, Ulloa HU, Peña JLR. Estudio de fibras colágenas y elásticas del tejido conjuntivo de pacientes con y sin hernia inguinal primaria. Rev Med Chil. 2003;131:1273-9.

5. Cannon DJ, Read RC. Metastatic emphysema: a mechanism for acquiring inguinal herniation. Ann Surg. 1981;194:270-8.

6. Conner WT, Peacock EE Jr. Some estudies on the etiology of inguinal hernia. Am J Surg. 1973;126:732-5.

7. Danneman A. Etiopatogenese das hérnias inguinais diretas. Rev Col Bras Cir. 1976;3:66-80.

8. Friedman DW, Boyd CD, Norton P, Greco RS, Boyarsky AH, Mackenzie JW, Deak SB. Increases in type III collagen gene expression and protein synthesis in patients with inguinal hernias. Ann Surg. 1993;218:754-60.

9. Grosfeld JL. Current concepts in inguinal hernia in infants and children. World J Surg. 1989;13:506-15.

10. Klinge U, Zheng H, Si ZY, Schumpelick V, Bhardwaj R, Klosterhalfen B. Synthesis of type I and III collagen, expression of fibronectin and matrix metalloproteinases- 1 and -13 in hernial sac of patients with inguinal hernia. Int J Surg Investig. 1999;1:219-27.

11. Klinge U. Altered collagen synthesis in fascia transversalis of patients with inguinal hernia. Hernia. 1999;3:181-7.

12. Lichtenstein I, Amid PK, Shulman AG. Open "tension-free" repair of inguinal hernias: The Lichtenstein technique. Eur J Surg. 1996;162:447-53.

13. Liem MS, van der Graaf Y, Beemer FA, van Voroonhoven TJ. Increased risk for inguinal hernia in patients with Ehlers Danlos syndrome. Surgery. 1997;122:114-5.

14. Liem MS, van der GraafY, van Steensel CJ, Boelhouwer RU, Clevers GJ, Meijer WS, Stassen LP, Vente JP, Weidema WF, Schrijvers AJ, van Vroonhoven TJ. Comparison of conventional anterior surgery and laparoscopic surgery for inguinal hernia repair. N Engl J Med. 1997;336:1541-7.
15. Montes GS, Junqueira LC. The use of the Picrosirius-polarization method for the study of biopathology of collagen. Mem Inst Osvaldo Cruz. 1991;86 (Suppl 3):1-11.

16. Nyhus LM. Individualization of hernia repair: a new era. Surgery. 1993;114:1-2.

17. Pans A, Pierard GE, Albert A, Desaive C. Adult groin hernias: a new insight into their biomechanical characteristics. Eur J Clin Invest. 1997;27:863-8.

18. Pans A, Albert A, Lapiére CM, Nusgens B. Biochemical study of collagen in adult groin hernia. J Surg Res. 2001;95:107-13.

19. Peacock EEJ. Internal reconstruction of the pelvic floor for recurrent groin hernia. Ann Surg. 1984;200:321-7.

20. Pickering JG, Boughner DR. Quantitative assessment of the age of fibrotic lesions using polarized light microscopy and digital image analysis. Am J Pathol. 1991:138:1225-31.

21. Read RC. Attenuation of the rectus sheath in inguinal herniation. Am J Surg. 1970;120:610-4..

22. Rodrigues Jr AJ, Rodrigues CJ, da Cunha AC, Jin Y. Quantitative analysis of collagen and elastic fibers in the fascia transversalis in direct and indirect inguinal hernia. Rev Hosp Clin Fac Med São Paulo. 2002;57:265-70.

23. Rosh R, Klinge U, Si ZY, Junge K, Klosterhalfen B, Schumpelick V. A role for the collagen I/III and MMP-1/-13 genes in primary inguinal hernia. BMC Medical Genetics. 2002;3:1471-2350.

24. Schumpelick V, Treutner KH, Arlt G. Inguinal hernia repair in adults. Lancet 1994;344:375-9

25. Wagh PV, Read RC. Collagen deficiency in the rectus shealth of patients with inguinal herniation. Proc Soc Exp Biol Med. 1971;137:382-4.

26. Wagh PV, Leverich AP, Sun CN, White HJ, Read RC. Direct inguinal herniation in men: a disease of collagen. J Surg Res. 1974,17:425-33.

27. Wolwacz Jr I, Trindade MR, Cerski CT. O colágeno em fáscia transversal de pacientes com hérnia inguinal direta submetidos à videolaparoscopia. Acta Cir Bras. 2003;18:196-202.

28. Zhang H, Sun L, Wang W, Ma X. Quantitative analysis of fibrosis formation on the microcapsule surface with the use of picro-sirius red staining, polarized light microscopy, and digital image analysis. J Biomed Mater Res A. 2006;76:120-5.

Recebido em 27/7/2006. Aprovado em 10/5/2007. 